\title{
Journal of Small Business and Enterprise Development
}

The use of the accounting beta as an overall risk indicator for unlisted companies Josée St-Pierre Moujib Bahri

\section{Article information:}

To cite this document:

Josée St-Pierre Moujib Bahri, (2006),"The use of the accounting beta as an overall risk indicator for unlisted companies", Journal of Small Business and Enterprise Development, Vol. 13 Iss 4 pp. 546 - 561

Permanent link to this document:

http://dx.doi.org/10.1108/14626000610705741

Downloaded on: 17 November 2016, At: 18:49 (PT)

References: this document contains references to 46 other documents.

To copy this document: permissions@emeraldinsight.com

The fulltext of this document has been downloaded 2094 times since 2006*

\section{Users who downloaded this article also downloaded:}

(2006),"SME exporting challenges in transitional and developed economies", Journal of Small Business and Enterprise Development, Vol. 13 Iss 4 pp. 535-545 http://dx.doi.org/10.1108/14626000610705732 (2006),"Change in SME internationalisation: an Irish perspective", Journal of Small Business and Enterprise Development, Vol. 13 Iss 4 pp. 562-583 http://dx.doi.org/10.1108/14626000610705750

\section{TELUO}

Access to this document was granted through an Emerald subscription provided by emerald-srm:230982 []

\section{For Authors}

If you would like to write for this, or any other Emerald publication, then please use our Emerald for Authors service information about how to choose which publication to write for and submission guidelines are available for all. Please visit www. emeraldinsight. com/ authors for more information.

\section{About Emerald www.emeraldinsight.com}

Emerald is a global publisher linking research and practice to the benefit of society. The company manages a portfolio of more than 290 journals and over 2,350 books and book series volumes, as well as providing an extensive range of online products and additional customer resources and services.

Emerald is both COUNTER 4 and TRANSFER compliant. The organization is a partner of the Committee on Publication Ethics (COPE) and also works with Portico and the LOCKSS initiative for digital archive preservation.

*Related content and download information correct at time of download. 
JSBED

13,4

546

\title{
The use of the accounting beta as an overall risk indicator for unlisted companies
}

\author{
Josée St-Pierre and Moujib Bahri \\ Small Business Research Institute, Université du Québec à Trois-Rivières, \\ Trois-Rivières, Canada
}

\begin{abstract}
Purpose - The purpose of this research is to verify whether or not the accounting beta, a recognized measure of overall risk in publicly traded companies, can be used with unlisted businesses.

Design/methodology/approach - The paper presents an empirical study using factorial and regression analysis to measure which components of the global risk of SMEs are linked to accounting beta.

Findings - The results show that accounting beta does not seem to constitute a global measure of SMEs' risk, being explained mostly by financial risk and not by commercial, technological, management and entrepreneurial risks components.

Research limitations/implications - Researchers will have to turn towards other models than accounting beta that include financial and nonfinancial dimensions of risk in order to obtain an adequate assessment of the overall SMEs' risk.

Practical implications - Risk is the element that determines access to external financing as well as the lending conditions. Results obtained in this research show that accounting data cannot be used to express overall risk of SMEs, because they are not global enough and are not good predictors of future situations.
\end{abstract}

Originality/value - This article presents limits inherent to financial data to properly measured global risk of SMEs.

Keywords Financial risk, Financial management, Small to medium-sized enterprises

Paper type Research paper

\section{Introduction}

Most enterprises will one day need to reach out to external sources of financing to ensure their development. Whether for investment in organizing their production, in their installations, or in their working capital, the firms that can depend indefinitely on their ability to generate all of their financial needs for development or operations are rare indeed. But, financing is not free and is not available under just any conditions. Indeed, these conditions are established in accordance with various parameters, most important of which is the risk that the business will default on its contractual obligations toward its lender and thus be unable to deal with its financial commitments. The conditions for obtaining and using these funds are defined in accordance with basic principles in finance that stipulate that any asset must yield a return proportional to the risk it entails for its title holder.

Journal of Small Business and Enterprise Development

Vol. 13 No. 4, 2006

pp. 546-561

(c) Emerald Group Publishing Limited $1462-6004$

DOI $10.1108 / 14626000610705741$

The authors would like to thank the J-Armand Bombardier Foundation for financing this research, as well as Canada Economic Development and the Canada Foundation for Innovation for making the creation of the database used in this study possible. 
The determination of the risk level of an enterprise as precisely as possible is then important, since this indicator will be utilized eventually to verify access to external financing and to determine under what conditions. Thus, the identification of SME risk poses a certain number of problems judging by the comments of the contractors on the possibilities of external financing and those of lenders, who consider de facto these enterprises as of very high risk (Laveren and Bortier, 2003; Pretorius et al., 2003; Rahman et al., 2003).

In spite of the fact that banks constitute the first source of external borrowing of the SMEs, several studies have shown that relations between these two business partners are laborious (see Belletante and Levratto (1995) and Jullien and Paranque (1995) for France; Maillat and Crevoisier (1996) for Switzerland; Janssen and Wtterwulghe (1998) for Belgium; St-Pierre and Bahri (2003) for Canada; and Lane and Quack (2001) for England). Bankers and entrepreneurs, operating in two different worlds, do not have the same reflexes and values in their respective management roles. It is not surprising then to see differences in how each perceives the other (Sarasvathy et al., 1998). A study by Pretorius et al. (2003) has shown some differences in the attitudes of bankers and entrepreneurs. While the bankers are averse to risk, the entrepreneurs are risk takers; the bankers have a short-term outlook and seek an immediate return, while the entrepreneurs aim for returns, both pecuniary and other, in the long term; for the bankers, guarantees are key to obtaining financing, while for the entrepreneurs it is of paramount importance to seize opportunities, and the acceptance of a loan request must be based on the project and not on guaranties.

Also, the bankers suspect that the entrepreneurs lack transparency in their loan request and in the utilization of the funds obtained while the entrepreneurs complain that their business risk is overvalued, resulting in financing conditions that are too harsh thereby diminishing their competitiveness. This observation has also been made in countries other than those listed above, but to different degrees, as demonstrated in the following studies. The cautious attitude of Malaysian bankers toward SMEs can be explained by the fact that they at times consider these enterprises as nonperformers (Rahman et al., 2003). For Belgian bankers, the SMEs present superior risks, given the differences between the objectives of management and those of the bankers, among other things (Janssen and Wtterwulghe, 1998). For their part, the bankers of South Africa are less inclined to finance SMEs because of their high level of risk and the weakness of their expected returns (Pretorius et al., 2003). The lenders also invoke the fact that the time spent evaluating a file must be proportional to the return they can draw from the transaction, which often places entrepreneur and banker at odds because the urgent needs of the first to ensure the company's development are not as important a preoccupation for the second.

Thus, it seems important to develop effective and efficient methods for measuring the borrower's risk that take into account all SME dimensions, including their intrinsic qualities, that could be pertinent indicators of their potential. We therefore endorse the position of Allegret (in Chanel-Reynaud and Bloy, 2001) who affirms that: "(...) the approach adopted by the banks within the framework of their financial diagnosis is unsuitable to the context in which enterprises, in particular the SMEs, currently evolve. In this way, the new financial diagnosis of an enterprise must be capable of taking into account the turbulence and recurring bumps that have affected enterprises since the early 80;" thus, the need to leave the usual framework in order to apprehend the overall

\section{The use of accounting beta}


JSBED

13,4

548 risk of the enterprise. The authors refer here to the financial framework usually used by lenders to determine the risk of an enterprise.

Preceding studies suggest that if we succeeded in developing an all-inclusive index of the overall risk of an SME, the lenders would find it easier to make rapid and objective decisions based on the reality of the business. Because such an index would reflect the body of risks, management could not reproach the financial system of an overvaluation of their risk, and thus of imposing financing conditions that they consider to be too harsh.

And yet, there are few models that allow evaluation of the total risk of a small enterprise. In banking circles, we often make use of "financial" models or models based in great measure on information taken from financial statements, since these are considered more objective than all other kinds of information (see Lévy and Sauvage, 2003 for the quotation system of the Banque de France; Müller, 2003 for Switzerland; St-Pierre, 2004 for Canada). However, we do not take into account the fact that the financial information does not reflect the structure of the enterprise, the quality of its business practices, or the various risk factors that can affect its performance from one day to the next, perhaps even its very survival. Risk is a "prospective" concept of a future event apt to hinder the realization of a particular objective (Hillson, 2004; Barthélémy, 2000). For a lender, risk is considered a threat and is linked with the event or situation that would prevent the enterprise from meeting its financial obligations. But, this event is rarely apparent in the financial statements. The fact that the future of the business rests on a key employee, or on a recent innovation, the decision of the enterprise to work with a concentrated or a diversified clientele, the use of avant-garde or outmoded technologies are some of the situations or events whose consequences are only reflected in the financial statements once they are reality, i.e. when it is too late to intervene.

Our study is intended first and foremost to be exploratory; it consists in verifying if an all-inclusive risk index such as the accounting beta, already tested in large and small publicly held corporations, can be considered as an overall measure of SME risk. In the present study, we wish to pursue the reflection that Vos (1992) initiated several years ago in his study on the SME accounting beta in which he invited researchers to work to better understand and develop specific measures of risk in unlisted businesses.

We will review in the next section the results of certain studies on the use of the accounting beta as a measure of risk in unlisted businesses. We will then summarize the principal factors impacting total SME risk that serve to define our empirical model. We will close with an analysis of the results as well as the conclusions and the limits of this research.

\section{Risk assessment in unlisted businesses}

The accounting beta as a measure of the overall risk in an SME

The financial literature suggests that the expected return on an asset $\left(R_{j}\right)$ depends on a risk-free rate that compensates the investor for the delay in his consumption over time and for the loss in purchasing power $\left(R_{f}\right)$, and a premium linked to the business and financial risks of the investment. This premium is determined by the amount of risk taken by the investor $\left(\beta_{j}\right)$ that multiplies the price of each unit of risk $\left(R_{m}-R_{f}\right)$. This relation, well known in finance and described by the Capital Asset Pricing Model (CAPM), can be expressed as:

$$
R_{j}=R_{f}+\beta_{j}\left(R_{m}-R_{f}\right)
$$


However, several researchers maintain that certain characteristics specific to SMEs impose limits on the pertinence of applying the CAPM in the context of these enterprises. Indeed, the CAPM rests on hypotheses that are only marginally realistic when applied in the context of privately held corporations (Khadjavi, 2003). The model assumes in this way that unsystematic risk can be eliminated by the diversification of the portfolio of the investor averse to risk, which implies that the total risk reduces to systematic risk. Now, the literature on venture capital seems to affirm that the specific risk occupies a particularly important place in unlisted corporations (Gompers and Lerner, 1999) because of the limited capacity of their owners to diversify their investment. The high cost of external funds, the investment of a large part of their wealth, and their total involvement in the management of their business constitute an obstacle to the diversification of their portfolio. Moreover, the nonmonetary benefits of control and the underestimation of the risks can, according to Moskowitz and Vissing-Jorgensen (2002), explain the lack of diversification by the entrepreneurs. This absence of diversification of human and financial capital in SMEs (McMahon et al., 1993) implies that the expected returns are linked to factors other than those covered by the systematic risk. However, this does not invalidate the application of the CAPM to the SMEs, but necessitates certain adjustments in the components of the model (Vos, 1992; McMahon et al., 1993).

The risk-free rate $\left(R_{f}\right)$ is estimated from the return on stock considered safe in the economy, such as the return on federal bonds whose term is equivalent to the period of the investment, while the price of each unit of risk is a function of the spread between the return of a market portfolio or one made up of shares that reflect the whole of the economy $\left(R_{m}\right)$ and the risk-free rate. When the enterprise shares are traded on the stock exchange, the risk coefficient $\left(\beta_{j}\right)$ that measures the systematic risk is relatively easy to estimate subject to certain hypotheses, but it is quite different with the shares of private companies (McMahon et al., 1993). In that case, we can use two different approaches for its estimation. We can resort to the stock exchange data of a company with similarities to the firm studied, and calculate its beta coefficient. A regression between the return obtained for this share and the returns obtained for a market portfolio will allow the determination of an approximate beta coefficient. When required, a correction for the debt difference between this enterprise and the private corporation could be made. However, one of the limits to this method is the difficulty in finding a firm really similar to the SME to be evaluated. Another way of estimating this coefficient is to utilize the accounting data published regularly by the enterprises. The coefficient thus obtained is the accounting beta[1]. The advantage in this method is that it takes into account directly information on the firm, thus its intrinsic risk factors, which is not the case with the preceding method. However, the literature does not indicate which risk factors are taken into account by the accounting beta, which is what we propose to verify in the present study.

Vos's (1992) study is among the very few where the adequacy of the accounting beta in measuring the total risk in unlisted businesses was tested. As in several other studies (Ball and Brown, 1969; Beaver et al., 1970; Beaver and Manegold, 1975; Ismail and Kim, 1989), his results show a positive correlation between the market betas and the accounting betas in small public corporations for two of the three years covered by the study. Vos examined the risk-return relation in a sample of 65 public corporations and 44 private corporations in New Zealand. He found that there is greater variance in

\section{The use of accounting beta}

549 
JSBED

13,4

550 accounting betas among private companies than is the case with public ones. Moreover, they are not linked with accounting profit in any significant way, while this relation is significant in the case of public corporations. The author then affirms that the accounting beta seems to be an incomplete measure of risk for SMEs; he suggests the development of a new model that allows the return of a private corporation to be linked to various components of risk among which, in an explicit way, a specific premium for the risk linked to the company that the investor cannot diversify. Furthermore, Vos (1992) invites researchers to try to better define SME risk, which is what we propose to do by examining the risk factors associated with the accounting beta.

The various components of risk in SMEs

It would seem that no commonly accepted definition of risk can be extracted from the literature; there is also little agreement on how to measure it. The comprehension of risk by researchers differs with the objective pursued, the utilization hoped for, and the type of organization studied. This may be why models of risk evaluation are often incomplete when attempting to estimate the total risk of a company. In an SME context, determining the elements of total risk is relatively complex because of their great heterogeneity and the difficulty in separating property from management. The entrepreneurs often have objectives that are implicit (Julien and Marchesnay, 1996), very variable (LeCornu et al., 1996), and at times unique (Naffziger et al., 1994), which will influence their management practices and render SMEs difficult to compare with one another. The literature contains a range of models for diagnosing risk that deal with this SME heterogeneity by adopting specific points of view like those of the lenders and managers (St-Pierre, 2004; Aubert and Bermard, 2004). Given the point of view adopted, these models identify elements of risk that they attach to generic dimensions. To better grasp the risks that confront the SME, it is important to follow a systemic approach and to consider the points of view of different authors that are often complementary, as we can see in what follows.

In a study on bankers, Wynant and Hatch (1991) recognized that the measure of total risk of the borrower's credit by the banker constitutes a complex task and depends on several factors. According to them, the total SME risk can be divided into: business risk (threat of the environment, lack of adequate skills and resources within the company, etc.), influenced by industry and market conditions, the firm's antecedents, its size, and the fitness of the management team; and financial risk (debt structure relative to revenue).

Similarly, Twarabimenye (1995) defined the criteria for evaluating loan-specific risk by bankers. The author identified three types of risk encountered by SMEs: the managerial risk (level of management qualification, planning for the changing of the guard, degree of managerial commitment); the macroeconomic risk (tendency of the GDP, anticipated return of the industry); and the financial risk (profitability level, debt load, asset productivity, level of working capital, and value of the guaranties).

Carlton (1999) is also interested in the identification of as complete a typology as possible and consolidates this information in a schedule of risks with which a business must deal: the strategic risks (bad marketing strategy, etc.), the financial risks (cash flow problems, etc.), the operational risks (design errors, sabotage, etc.), the business 
risks (problems with suppliers, disrespect for legal circumstances, etc.), and the technical risks (equipment problems, etc.).

To determine a risk-related premium applied to SMEs, Cotner and Fletcher (2000) identified five factors each of which is made up of at least two elements of risk. The revenue related risk factor is composed of the level, variability, and growth rate of sales. The operational risk factor is linked to the level of the fixed exploitation costs. The financial risk factor is linked to the coverage of the interests, the capacity for indebtedness, and the composition of the debt. The management and control risk factor is linked to the confidence of the investors in the management team, to the organizational experience, and to the type of control (family property, minority stockholders, etc.). Finally, the strategic risk factor considers the position of the firm relative to its suppliers, its clients, the existing market competitors, and the threat of new inputs and that of substitutes.

St-Pierre (2004) recognizes that the total risk of the enterprise depends on the business or operational risk, the financial risk, and the entrepreneurial risk. The business risk is made up of the management risk (lack of knowledge about management and lack of human resources, insufficiency of resources devoted to management, etc.), commercial risk (potential market, possibility of losing an important client, reaction of competitors, fluctuations in demand, distribution difficulties, etc.), and technological risk (production structure, utilization of an inadequate technology, absence of technological development monitoring, absence of $\mathrm{R} \& \mathrm{D}$ or continuous improvement activities, etc.). The financial risk is related mainly to capital structure, to the identity and origin of the financial partners, to the financing contracts (redemtion dates and restrictive clauses), and to the capacity for reinvestment by the current owners. Finally, the entrepreneurial risk depends mostly on the personality of the director, his aversion to risk, and his personal objectives with regard to the development and organization of his business.

These different models reflect the multidimensional character of the enterprise and provide information on the various elements that make up the total risk of the SME, i.e. the business risk and the financial risk. In Table I, we propose a synthesis of these risk elements that we have classified as the management risk, the commercial risk, the technological risk, the financial risk, and the entrepreneurial risk.

Management risk

Commercial risk

Technological risk

Financial risk

Entrepreneurial

risk
Lack of management tools (ex. cash flow budget), absence of a board of directors or management committee, absence of a designated head for each of the company's functions

Competitive position of the company; actual and potential markets; competitor reaction; demand fluctuations; distribution difficulties Problems with suppliers; lack of production personnel training; problems with the equipment; inadequate production structure, absence of technological development monitoring, absence of $R \& D$ or continuous improvement activities

Profitability level; debt load; interest coverage; capacity for indebtedness; financing contracts (redemption dates and restrictive clauses); capacity for reinvesting by the current owners Age, experience, and training of the owner-manager

\section{The use of accounting beta}

551 
JSBED

13,4

552

The hypothesis we propose to verify can then be written as:

$$
\begin{gathered}
\text { Accounting beta }=f\left(\text { Risk }_{\text {management }} ; \text { Risk }_{\text {commercial }} ; \text { Risk }_{\text {technological }} ;\right. \\
\text { Risk } \left._{\text {financial }} ; \text { Risk }_{\text {entrepreneurial }}\right)
\end{gathered}
$$

where the measurement of the accounting beta is equivalent to that used by Vos (1992):

$$
\text { Accounting beta }=\left(\Delta \mathrm{ROE}_{i} / \Delta \mathrm{ROE}_{m}\right)
$$

where:

$\Delta \mathrm{ROE}_{i}=$ the variation in the return on the stockholders' assets (capital) of the enterprise based on two successive periods;

$\Delta \mathrm{ROE}_{m}=$ the variation in the return on the stockholders' assets (capital) of a market (sectorial) portfolio based on the same two successive periods.

\section{Methodology and results}

Description of the sample used

The data used in the present study were taken from the database PDG ${ }^{\circledR}$ containing information on more than 300 Canadian "private" manufacturing SMEs having between 10 and 450 employees. The information extracted had to do with, among other things, the personal details of the entrepreneur (age, experience, willingness to share control of his company, desire for growth, strategic orientation), business practices utilized by the company in management and human resources, production, market development, control, production systems utilized, innovation and export activities, strategic alliances, investments made in the management and production technologies, as well as the financial statements of the last five years. After eliminating the observations containing missing data, the final sample on which our study rests involves 128 SMEs. Table II lists some characteristics of the sample where we can see some diversity, as indicated by the dispersion in the data.

\section{Analysis of the results}

To verify the hypothesis of this research, we have used a two-step approach. The first step in our procedure consists of identifying the variables that contribute the most to the definition and explanation of the overall risk of the enterprise. Since the specific determinants of each of the components of the overall risk of SMEs are not that well identified in the literature, we have decided to use a great

\begin{tabular}{lcc}
\hline & Average & Standard deviation \\
\hline Age of the enterprise & 23.6 years & 18.0 years \\
Number of employees & 75 & 71 \\
Sales (in Canadian $\$$ ) & $10,025,151$ & $10,078,087$ \\
Export rate (\%) & 23 & 28 \\
$\%$ of sales to the three principal clients & 43 & 25 \\
Bank indebtedness ratio (\%) & 36.22 & 17.13 \\
Gross profit margin (\%) & 25.04 & 9.98 \\
Net profit margin (\%) & 4.37 & 4.36 \\
\hline
\end{tabular}

Table II.

Some of the variables that describe the sample

Gross profit margin ( $\%)$
Net profit margin ( $\%)$

Age of the enterprise

Number of employees

Sales (in Canadian \$)

Export rate $(\%)$

$\%$ of sales to the three principal clients 
number of the indicators linked to the risk factors identified above (see Table I) and included in the database, i.e. the elements that can affect management risk, commercial risk, technological risk and entrepreneurial risk. To reduce the large number of indicators to a few principal dimensions reflecting the types of risk, we have started with factor analysis.

The factor analysis that allows validation of the construct (Kerlinger, 1986) is used to reduce the number of risk indicators into constructs representing the different types of risk the enterprise is confronted with. These constructs are then used in a multiple regression analysis, where the accounting beta is the dependent variable. Factor analysis is sensitive to sample size. In the present study, each type of risk is examined separately. In this way, for example, the reduction of the indicators that represent the commercial risk as a construct is carried out independently of the indicators of management risk. We have respected the ratio 5:1, i.e. a minimum of five observations for each indicator of this construct (Tabachnick and Fidell, 1989). All the factors identified have an adequacy index of the factorial solution measured by Kaiser-Meyer-Olkin (KMO) that exceeds 0.5, which complies with the suggestions of Hair et al. (1995) who note that a KMO less than 0.5 is unacceptable. Table III shows the components of each of the risk factors and their saturation coefficients, which measure the strength of the bond between the indicator and the factor associated with it. The results shown indicate that the management risk is associated primarily with the utilization of management tools in the enterprise (budgeted financial statements, cash flow) and the presence of a board of directors. Commercial risk is associated with the follow-up of current and potential clients as well as competitor analysis. Technological risk is primarily associated with the training of foremen and production employees and

\begin{tabular}{llr}
\hline Type of risk & Variables & $\begin{array}{c}\text { Saturation coefficient } \\
(n=128)\end{array}$ \\
\hline Management risk & Use of budgeted financial statements & $0.66560^{\mathrm{a}}$ \\
& Presence of a board of directors & 0.62094 \\
& Use of a cash flow budget & $0.60152^{\mathrm{a}}$ \\
& Designated head for the various functions & $0.45796^{\mathrm{a}}$ \\
& Training of managers & $0.41768^{\mathrm{a}}$ \\
& Market study of current clients & $0.82218^{\mathrm{a}}$ \\
& Market study of potential clients & $0.79104^{\mathrm{a}}$ \\
Technological risk & Competitor analysis & $0.70292^{\mathrm{a}}$ \\
& Training of foremen & $0.79146^{\mathrm{a}}$ \\
& Training of production employees & $0.71697^{\mathrm{a}}$ \\
& Collaboration with a supplier for production & $0.55090^{\mathrm{a}}$ \\
& Collaboration with a client for production & $0.51624^{\mathrm{a}}$ \\
& Collaboration in R\&D & $0.49134^{\mathrm{a}}$ \\
& Interest coverage ratio & $0.89757^{\mathrm{a}}$ \\
& Short-term debt & $-0.77272^{\mathrm{a}}$ \\
Entrepreneurial risk & Level of liquidities & $0.75571^{\mathrm{a}}$ \\
& Age of the owner-manager & $0.83231^{\mathrm{a}}$ \\
& Experience in management & $0.77503^{\mathrm{a}}$ \\
& Training of the owner-manager & $-0.45847^{\mathrm{a}}$
\end{tabular}

Note: ${ }^{\mathrm{a}} p<0.0001$

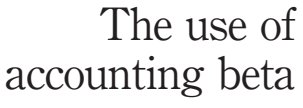

553

Table III.

Factor analysis in principal components 
JSBED

13,4

554

collaboration with different partners. Financial risk is associated with the interest coverage ratio, the short-term debt, and the level of liquidities. The entrepreneurial risk is expressed primarily by the age and experience of the owner-manager.

The second step in our procedure consists of introducing into a regression analysis the five factors retained from the factor analysis. The objective of this procedure is to verify the related influence of these risk factors on the accounting beta. We have tested three regression models, with the results shown in Table IV. The first model demonstrates the high degree of significance (0.0001) of the factor "financial risk" in the explanation of the accounting beta. The importance of this factor is verified by its contraction in regressions (Model 2), where we can see that the adjusted coefficient of determination goes from 28.46 percent to an insignificant 1.76 percent (Fisher Test). Finally, as seen in the third model, this factor alone among those retained contributes the better part of the variance in the coefficient Beta (0.2713).

The results shown in Table IV do no allow the risk indicators that best explain the accounting beta to be identified with precision. We have retained the indicators making up the risk factors (Table III) for a second regression analysis to verify their influence on the accounting beta. The stepwise regression method is used in order to identify only those independent variables (risk indicators) that are significant in explaining the accounting beta.

Model 4 in Table $\mathrm{V}$ shows the influence of these variables on the accounting beta. The adjusted coefficient of regression obtained is 0.6204 , clearly greater than that obtained with the use of factors (0.2846). The level of liquidities representing the financial risk is the most significant variable of the model; to this is added the interest coverage ratio, the training of managers, and the collaboration with clients on matters of production. To more fully appreciate the role of the measure of the liquidities and of the interest coverage ratio that represent the financial risk in the explanation of the accounting beta, we have eliminated them from Model 5; we then observe a substantial decline in the adjusted coefficient of determination (from 0.6204 to 0.0433 ). These results suggest the importance of the financial risk, as measured by the level of liquidities and the interest coverage ratio, and the very weak impact of the indicators of the business risk and the entrepreneurial risk in the determination of the accounting beta. This is further confirmed in Model 6, where the liquidity level and the interest coverage ratio alone account for more than 58 percent of the observed variance in the accounting beta.

Table IV.

Relation between some risk "factors" and the accounting beta of the SMEs

\begin{tabular}{lrrrrrr}
\hline & \multicolumn{2}{c}{ Model 1 } & \multicolumn{2}{c}{ Model 2 } & \multicolumn{2}{c}{ Model 3} \\
& $n=128$ & Probability & $n=128$ & Probability & $n=128$ & Probability \\
\hline Ordinate at the origin & 0.07101 & 0.3524 & 0.0094 & 0.9154 & 0.06448 & 0.3961 \\
Factor: financial risk & 0.53664 & $<0.0001$ & & & 0.53304 & $<0.0001$ \\
Factor: management risk & 0.03359 & 0.6795 & -0.03596 & 0.7035 & & \\
Factor: business risk & 0.08034 & 0.3206 & 0.14906 & 0.1141 & & \\
Factor: technological risk & -0.19282 & 0.0212 & -0.18804 & 0.0543 & & \\
Factor: entrepreneurial risk & 0.06319 & 0.4005 & 0.00051 & 0.9953 & & \\
Fisher test $(F$-value) & 11.10 & $<0.0001$ & 1.57 & 0.1870 & 48.28 & $<0.0001$ \\
$R^{2}$ & 0.3128 & & 0.0485 & & 0.2770 & \\
Adjusted $R^{2}$ & 0.2846 & & 0.0176 & & 0.2713 & \\
& & & & & &
\end{tabular}




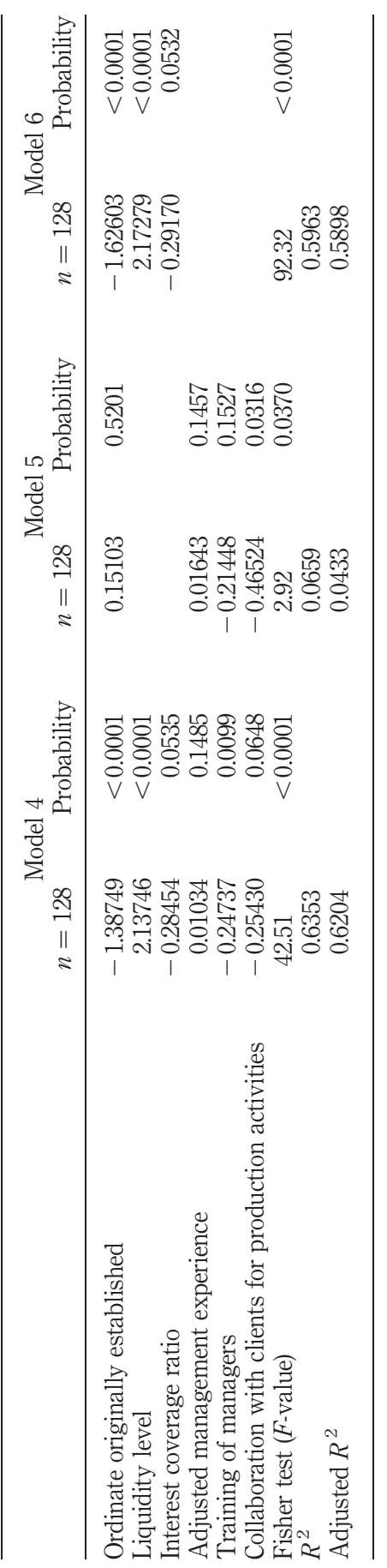

The use of accounting beta

555

Table V.

Relationship between risk indicators and the accounting beta of the SMEs 
JSBED

13,4

556
All of the results obtained in the context of this exploratory analysis lead to the observation that the accounting beta does not seem sufficient as a measure of the overall risk of SMEs, being linked very closely to the financial dimensions of the enterprise. As we have already stated, these dimensions are not prospective and do not allow anticipation of possible problems in the enterprises that could help the lenders to detect future bad debtors. This discussion on the capacity of financial data to measure "overall" the risk of SMEs is as pertinent as that in use for about twenty years according to which the financial statements of the enterprises yield significant limits on the evaluation of their performance.

In the early 1980s, a certain number of authors criticized accounting models to measure the performance of organizations in a turbulent and highly competitive business environment (Gomes et al., 2004; Kennerley and Neely, 2003; Said et al., 2003; Medori and Steeple, 2000). Cumby and Conrod (2001) added that the limits of accounting or financial measurements are even more important or flagrant for innovative companies, where value is strongly linked to intangible assets and intellectual capital (Amir and Lev, 1996). We thus criticize measurements derived from financial statements by the fact that they are historic and offer little indication on future performance, not taking into account intangible elements of the value of an enterprise and not being tied to the strategy pursued by the management (Kennerley and Neely, 2003; Ittner et al., 2003; Kaplan and Norton, 2001).

\section{Conclusion}

The development of a model allowing a synthetic risk rating to be defined for privately-held companies is a subject that has not attracted the attention of researchers these last few years. On the other hand, it is a subject of great importance to the extent that such a rating would permit a more acute definition of the real risk of a privately held corporation and, consequently, eventual access to external financing and financing conditions.

The results obtained in this study lead to the observation that the accounting beta does not capture all the dimensions of SMEs' risk but focus almost exclusively on the financial information. As emphasized by Eccles (1999), the financial data cannot yield all the dimensions of enterprise performance. Indeed, quality, client satisfaction, innovation, and market share are elements of strategic information that better reflect the competitivness and the performance of an enterprise, but that do not necessarily find expression in the income earned. Also, Cumby and Conrod (2001) remind us that the financial performance "sustainable" in the long term is attributable to nonfinancial factors like client loyalty, employee satisfaction, internal processes, and the degree of innovation of the business. Ittner and Larcker (1998) agree completely by affirming that the accounting data cannot take into account the investment in intangible assets such as client satisfaction. The same remains true for the factors of vulnerability or the risk of enterprises that we find difficult to comprehend from a prospective point of view through financial statements.

Our conclusions go beyond those of Vos (1992), who suggested that it was necessary to add a "size premium" for privately-held corporations. Finding inspiration in the literature on the failure of enterprises, we suggest adding under certain conditions to the financial data nonfinancial information related to the organization of the business, its ways of doing things, the particularities of its market, its decision-making structure, 
and the indicators of vulnerability that could "explain" the financial data. Making greater use of this nonfinancial information, we can also counter the problems related to the manipulation of financial statements, to their historic and temporal character.

In a globalization context where great pressure is constantly applied on SMEs for an increased use of new management and production technologies, continuous innovation, and the adoption of good business practices, time will play an increasingly critical role. Thus, a "rapid" evaluation of risk using an overall and prospective model could certainly contribute in facilitating access to external financial resources that could be essential to their development, within waiting periods that take into account the demands of competitiveness.

\section{Limitations and further research}

The principal limit of this research is its external validity. The sample is non-probabilistic and may not be representative of all manufacturing SMEs. Other studies on other samples are needed to validate our conclusions. Another limit of this research concerns measurement of non financial risk indicators that are to be explored more deeply to assure their validity.

Being essentially exploratory, this research may be extended to further our understanding of components of SMEs' risks and try to find an all-inclusive index that could shorten delays in decision making. We do not know for sure if accounting beta is not an appropriate measure. The results presented here are too partial to formulate this conclusion. We must increase the number of nonfinancial being helped by literature on bankruptcy and new literature on risk management inspired by project management concepts (Hillson, 2004), to capture more globally all dimensions of risk. Also, to further investigate the components of overall SMEs' risk we should conduct empirical study on a sample of firms having expressed financial difficulties and explore links between nonfinancial variables and financial results. Finally a possible lag effect may exist between non financial variables and financial ones that should be studied on a longitudinal basis.

\section{Note}

1. The accounting beta can be obtained by dividing the variation in the return on capital of the business based on two successive periods by the variation in the return on capital of a market (sectorial) portfolio based on the same two successive periods.

\section{References}

Amir, E. and Lev, B. (1996), "Value-relevance of nonfinancial information: the wireless communications industry”, Journal of Accounting and Economics, Vol. 22, pp. 3-30.

Aubert, B.A. and Bermard, J.-G. (2004), Mesure intégrée du risque dans les organisations, Les Presses de l'Université de Montréal, Montreal.

Ball, R. and Brown, P. (1969), "Portfolio theory and accounting theory", Journal of Accounting Research, Vol. 7, pp. 300-23.

Barthélémy, B. (2000), Gestion des risques: Méthode d’optimisation globale, Editions de l'Organisation.

Beaver, B., Kettler, P. and Scholes, M. (1970), "The association between market determined and accounting determined risk measures", The Accounting Review, Vol. 45, pp. 654-82.

\section{The use of accounting beta}

557 
JSBED 13,4

\section{8}

Beaver, W. and Manegold, J. (1975), "The association between market determined and accounting determined measures of systematic risk: some further evidence", Lournal of Financial and Quantitative Analvsis, Vol. 10, pp. 231-84.

Belletante, B. and Levratto, N. (1995), "Finance et PME: quels champs pour quels enjeux?", Revue Internationale PME, Vol. 8 Nos 3-4, pp. 5-42.

Carlton, T. (1999), "Risk and capital management in non-financial companies", Risk and Capital Management Conference Proceedings, Australian Prudential Regulation Authority.

Chanel-Reynaud, G. and Bloy, E. (2001), La banque et le risque PME, Presses universitaires de Lyon, Lyon.

Cotner, J.S. and Fletcher, H.D. (2000), "Computing the cost of capital for privately held firms", American Business Review, Vol. 18 No. 2, pp. 27-33.

Cumby, J. and Conrod, J. (2001), "Non-financial performance measures in the Canadian biotechnology industry", Lournal of Intellectual Cabital, Vol. 2 No. 3, pp. 261-72.

Eccles, R.G. (1999), "Le manifeste de l'évaluation des performances”, in "Les systèmes de mesure de la performance", Harvard Business Review, Editions de l'Organisation.

Gomes, C.F., Yasin, M.M. and Lisboa, J.V. (2004), "An examination of manufacturing organizations' performance evaluation”, International Iournal of Operations \& Production Management, Vol. 24 No. 5, pp. 488-513.

Gompers, P.A. and Lerner, J. (1999), The Venture Capital Cycle, MIT Press, Cambridge, MA.

Hair, J.F. Jr, Anderson, R.E., Tatham, R.L. and Black, W.C. (1995), Multivariate Data Analysis with Readings, 4th ed., Prentice-Hall International, Upper Saddle River, NJ.

Hillson, D. (2004), Effective Opportunity Management for Projects: Exploiting Positive Risk, Marcel Dekker, New York, NY.

Ismail, B.E. and Kim, M.K. (1989), "On the association of cash flow variables with market risk: further evidence", Accounting Review, Vol. 64, pp. 125-36.

Ittner, C.D. and Larcker, D.F. (1998), "Are nonfinancial measures leading indicators of financial performance? An analysis of customer satisfaction", Iournal of Accounting Research, Vol. 36, pp. 1-35.

Ittner, C.D., Larcker, D.F. and Randall, T. (2003), "Performance implications of strategic performance measurement in financial services firms", Accounting. Organizations and Societv, Vol. 28, pp. 715-41.

Janssen, F. and Wtterwulghe, R. (1998), "L'influence de l'interprénétration du dirigeant et de son entreprise sur l'endettement bancaire des PME: état de la question", paper presented at 4ième Congrès International Francophone de la PME, Metz, France, octobre.

Julien, P.-A. and Marchesnay, M. (1996), "L'entrepreneuriat”, Économica.

Jullien, H. and Paranque, B. (1995), "Financement des entreprises et évolution du système financier", Revue Internationale PME, Vol. 8 Nos 3-4, pp. 43-66.

Kaplan, R.S. and Norton, D.P. (2001), "Transforming the balanced scorecard from performance measurement to strategic management: Part 1", Accounting Horizons, Vol. 15, pp. 87-104.

Kennerley, M. and Neely, A. (2003), "Measuring performance in a changing business environment", International Journal of Operations \& Production Management, Vol. 23 No. 2, pp. 213-29.

Kerlinger, F.N. (1986), Foundations of Behavioral Research, 3rd ed., Holt, Rinehart \& Winston, Fort Worth, TX. 
Khadjavi, K. (2003), Specifics of Valuation in Private, Manager-owned Companies - A CAPM Approach, Universitat St-Gallen-Hochschule für Wirtschafts-, Rechts- und Sozialwissenschaften.

Lane, C. and Quack, S. (2001), "How banks construct and manage risk: a sociological study of small firm lending in Britain and Germany", working paper No. 217, ESRC Centre for Business Research, University of Cambridge, September.

Laveren, E. and Bortier, J. (2003), "Bank financing and SMEs: survey results and policy implications", Actes de la 48ième conférence mondiale du International Council for Small Business, Belfast.

LeCornu, M.R., McMahon, R.G.P., Forsaith, D.M. and Stanger, A.M.J. (1996), "The small enterprise financial objective function”, Lournal of Small Business Management, Vol. 34 No. 3, pp. 1-14.

Lévy, J. and Sauvage, F. (2003), "La cotation de la Banque de France et le ratio McDonough", Bulletin de la Banque de France, No. 112, available at: www.banque-France.fr/fr/telechar/ bulletin/etu112_1 (accessed 20 December 2005).

McMahon, R.G.P., Holmes, S., Hutchinson, P.J. and Forsaith, D.M. (1993), Small Enterprise Financial Management: Theory and Practice, Harcourt Brace, Sydney.

Maillat, D. and Crevoisier, O. (1996), "Le financement du développement endogène dans l'Arc Jurassien”, Dossier de recherche, No. 38, Institut de recherches économiques et régionales, Université de Neufchâtel.

Medori, D. and Steeple, D. (2000), "A framework for auditing and enhancing performance measurement systems", International Iournal of Operations \& Production Management, Vol. 20 No. 5, pp. 520-33.

Moskowitz, T.J. and Vissing-Jorgensen, A. (2002), "The returns to entrepreneurial investment: a private equity premium puzzle?", The American Economic Review, September, pp. 745-78.

Müller, H.-U. (2003), "Notation interne: exemple Crédit Suisse”, available at: www.cvci.ch/upload/ Public/Discours/Zuberbuhler03.ppt (accessed 18 December 2005).

Naffziger, D.W., Hornsby, J.S. and Kuratko, D.F. (1994), “A proposed research model of entrepreneurial motivation”, Entrepreneurship Theory \& Practice, Vol. 18, pp. 29-42.

Pretorius, M., Shaw, G. and Van Vuuren, J. (2003), "Business plans in bank decision-making when financing new ventures", paper presented at 48th World Conference International Council for Small Business, Belfast.

Rahman, G.A., Mahmood, R. and Rahman, N.A.A. (2003), "Bank selection criteria: comparing bankers and the small business owners", paper presented at 48th World Conference International Council for Small Business, Belfast.

Said, A.A., HassabElnaby, H.R. and Wier, B. (2003), "An empirical investigation of the performance consequences of non-financial measures", Lournal of Management Accounting Research, Vol. 15, pp. 193-223.

St-Pierre, J. (2004), La gestion du risque: comment améliorer le financement des PME et favoriser leur développement, Presses de l'Université du Québec, Quebec.

St-Pierre, J. and Bahri, M. (2003), Relations entre la prime de risque bancaire des PME et les composantes de leur risque global, Association canadienne des sciences administratives, ASAC, Halifax.

Sarasvathy, D.K., Simon, H.A. and Lave, L. (1998), "Perceiving and managing business risks: differences between entrepreneurs and bankers", Lournal of Economic Behavior and Organization, Vol. 33, pp. 207-25. 
JSBED

13,4

560
Tabachnick, B.G. and Fidell, L.S. (1989), Using Multivariate Statistics, 2nd ed., Harper \& Row, New York, NY.

Twarabimenye, P. (1995), "Modèle d'aide à l'évaluation du risque de prêt aux entreprises", Thèse de doctorat en administration, Université du Québec à Montréal.

Vos, E. (1992), "Differences in risk measurement for small unlisted businesses", Journal of Small Business Finance, Vol. 1 No. 3, pp. 255-67.

Wynant, L. and Hatch, J. (1991), Banks and Small Business Borrowers, The Western Business School, The University of Western Ontario, London.

\begin{abstract}
About the authors
Josée St-Pierre is Professor of Finance and holder of the J.A. Bombardier Chair on interenterprise relations and risk management; her research interests include the determinants of SME performance and vulnerability as well as the elements that create and diminish value.

Moujib Bahri is a Doctorate candidate in Administration, his research is on the utilisation of EVA by manufacturing SMEs. He is the corresponding author and can be contacted at: Moujib.bahri@uqtr.ca
\end{abstract}

(See opposite page for the Appendix.) 


\section{Appendix}

Variables
Utilization of budgeted financial
statements
Presence of a board of directors
Utilization of a cash flow budget
Positions with a designated head

Training of managers

Market study of current clients

Market study of potential clients

Competitor analysis

Training of foremen

Training for production employees

Collaboration with a client for production purposes

Collaboration with a supplier for

production purposes

Collaboration in the area of design and $\mathrm{R} \& \mathrm{D}$

Interest coverage ratio

Short-term bank indebtedness

Liquidity level

Training of the director
Measures

\section{Management risk}

Utilization of budgeted financial statements, yes $=1$ no $=$ 0

Presence of a board of directors, a consultative committee, or a management committee, yes $=1$, no $=0$

Utilization of a cash flow budget, yes $=1$, no $=0$

Percentage of management positions (production, marketing/sales, finances/accounting, quality assurance, $R \& D$, and management of human resources) assumed by a designated head other than the president

Training activities for managers (other than the director) (average number of hours per month). No training $=0$, training from 1 to 5 hours $=1$, training from 6 to 10

hours $=2$, training for 10 hours or more $=3$

Business risk

Frequency of market studies of current clients: 1 (weak) to 5 (strong)

Frequency of market studies of potential clients: 1 (weak) to 5 (strong)

Frequency of competitor analysis: 1 (weak) to 5 (strong) Technological risk

Training activities for foremen (team leaders) (average number hours per month). No training $=0$, training from 1 to 5 hours $=1$, training from 6 to 10 hours $=2$, training of 10 hours or more $=3$

Training activities for production employees (average number of hours per month). No training $=0$, training from 1 to 5 hours $=1$, training from 6 to 10 hours $=2$, training of 10 hours or more $=3$

Binary variable; if yes $=1$, no $=0$

Binary variable; if yes $=1$, no $=0$

Collaboration in the area of design and $R \& D$ with at least one business partner (purchaser, research centre, teaching institution, other SME, competitors, suppliers, clients), if yes $=1$, no $=0$

Financial risk

The ratio of earnings before interest and taxes to interest costs

(Credit margin utilized + Portion of the long-term debt due during the year)/total assets

Ratio of earnings plus sales to depreciation

Entrepreneurial risk

Training activities for the director (average number of hours per month). No training $=0$, training from 1 to 5 hours $=1$, training from 6 to 10 hours $=2$, training of 10 hours or more $=3$

\section{The use of accounting beta}

561
Table AI. The determination of the variables that represent risk indicators

\section{To purchase reprints of this article please e-mail: reprints@emeraldinsight.com}

Or visit our web site for further details: www.emeraldinsight.com/reprints 
This article has been cited by:

1. Bernd BritzelmaierPforzheim University, Pforzheim, Germany Patrick KrausPforzheim University, Pforzheim, Germany Michael HäberlePforzheim University, Pforzheim, Germany Benjamin MayerPforzheim University, Pforzheim, Germany Valentin BeckLeeds Metropolitan University, Leeds, UK. 2013. Cost of capital in SMEs. EuroMed Journal of Business 8:1, 4-16. [Abstract] [Full Text] [PDF]

2. Josée St-Pierre, Nazik Fadil. 2011. La recherche en finance entrepreneuriale. Revue internationale P.M.E.: Économie et gestion de la petite et moyenne entreprise 24:3-4, 255. [CrossRef] 